\title{
ICT as a sustainable economic solution for emerging countries
}

\author{
M. Abdollahpouri \\ Iranian Association of Information and Communication Technologies, \\ Amir Kabir University of Technology, Iran
}

\begin{abstract}
The goal of developing and planning affordable and sustainable solutions for emerging countries has come to the fore for policy makers and professionals in various disciplines. Examples of such solutions - in the fields of business, technology, innovation, education, livelihood, etc. - can be derived from the academic literature and/or executive reports. In this paper, the focus is on Information and Communication Technology (ICT) as a sustainable solution for the economies of emerging countries. It is suggested that for emerging countries, economic sustainability can be envisioned through the application of ICT with regard to the characteristics of their own markets. In order to investigate the impact of ICT as a sustainable solution, we firstly identify the specific characteristics of emerging countries and their markets. Then ICT's capacity for creating sustainability is presented in terms of the characteristics of emerging markets and economies. The types of ICTs relevant to the theme of emerging countries are highlighted, and the ways in which they can provide economically sustainable solutions. This research concludes with the way in which emerging markets have the capacity to take advantage of ICT because of their features of growing populations and low-cost labour markets. Emerging markets can also benefit from ICT to nurture skilled human capital, reduce volatility, bolster capital markets and shape a dynamic economy.

Keyword: ICT, emerging country, economic sustainability, offshoring, volatility, capital market, human resource.
\end{abstract}




\section{Introduction}

Information and communication technology (ICT) is now connected to almost all spheres, from everyday life to specialised areas, including economy. In particular, it has received a good deal of attention in the realm of business. ICT is defined as a set of hardware, software and communication networks required for collecting, processing, storing, distributing and retrieving information. In other words, ICT means the set of technologies and applications that provide access to information via telecommunication networks.

ICT can be linked to various themes and concepts across various disciplines. For example, it is highly associated with the term sustainability. Sustainability is the quality and ability to be maintained at a specific rate or level over time. A systematic approach towards sustainability constitutes economic, social and environmental aspects. Many literature resources can be found on the relationship between ICT and any of the aspects of sustainability.

The focus of the present paper is on the role of ICT in economic sustainability in the context of emerging countries. Various organisations and institutions have presented several definitions for emerging countries. However, they share some characteristics in their markets and economies. Emerging countries are known to have lower-than-average per capita incomes, rapid growth, high volatility, lessmature capital markets and higher-than-average returns on investment [1-3].

In order to analyse the impact of ICT on economic sustainability, we need to analyse its role with regard to the characteristics of emerging economies. Therefore, in the following sections, the focus will be on how ICT fits within the context of emerging countries and how it is relevant to various aspects of their economies, while considering the (potential) sustainability of its impact.

\section{ICT, rapid growth and low income}

Considering the economic aspects of sustainability and the low income and rapid growth characteristics of emerging countries, ICT substantially facilitates employment creation, economic growth and poverty alleviation [4]. ICT also raises demand for new skills and jobs. It influences employment, both as an industry itself and also as a required tool for other industries to operate in the digital era. Digitisation of more and more aspects of work, as brought about by ICT, has redefined practices, processes and standards in almost every industry and, more importantly, in business.

Incorporating ICT enhances the demand for professionals at various levels of skill and expertise, from programmers to managers who work in IT and telecommunications companies. In addition, as more industries and businesses enter into the electronic era, whether by integrating electronics into existing processes to some extent or a complete switch to digital platforms, new career opportunities continue to increase. This, in turn, creates a great need for skilled workers to sustain the existing availabilities and generate new opportunities in order to support and boost development. 
Human capital is considered as a driver of economic growth. A robust economy is to a large degree dependent on its human resource and workers' skills, as the economy of a country is actually run by its people. Emerging countries can benefit from their large and young human capital as a potential skilled workforce. Appropriate training and the right exposure to professional and educational knowledge provide a powerful, qualified workforce by which a country fosters its economic growth. Here, ICT has a dual role, creating employment and also making education accessible and affordable, for example through e-learning and mobile learning solutions.

Possessing skilled people is mirrored as a critical factor in the global trend of offshoring, also known as offshore outsourcing, since offshoring is a type of outsourcing. In outsourcing, non-critical business processes are transferred to third-party providers while the core processes are kept in-house; by offshoring, we mean that the external providers are located in another country. So, offshoring means outsourcing overseas.

Offshoring has emerged as a major trend in global business in recent years. According to the definition provided by the Organisation for Economic Cooperation and Development [5] 'offshoring is used to describe a business's (or a government's) decision to replace domestically supplied service functions with imported services produced offshore'. Another definition has been offered by the German Federal Association for IT, Telecommunication and New Media (BITKOM) [6], according to which 'offshoring can be defined as a special form of outsourcing where software development and other IT services are transferred to lower-cost destinations' (p. 18).

India is the emerging country that is the world's leading location for offshoring. According to the A.T. Kearney Global Services Location Index [7] - which tracks the contours of offshoring in more than 50 countries - India is number one, followed by China, Malaysia and Brazil. India benefits from its large Englishspeaking population, skilled labour and low wages, making it the most important destination for IT and ICT-relevant service outsourcing and offshoring in recent years [8]. China is also a popular offshoring location for large companies including IBM, GM and Apple - to shift their production and/or services. In addition to India and China, other developing and emerging countries have entered the offshoring market, particularly from Asia, Eastern Europe and Latin America, including Indonesia, Thailand, the Philippines, Poland, Romania, Bulgaria, Mexico, Costa Rica and Chile.

Emerging countries benefit from offshoring by practising competition at a local level to attract more companies to switch their processes to them. The competitiveness of local businesses and industries, in turn, is strengthened through securing local employment, productivity, innovation and value creation, leading to a dynamic economy. Moreover, with their economies incorporated in the international market, emerging markets have a global reach to help them evolve into globally competitive economies. 


\section{ICT and volatility}

Another characteristic often associated with the markets of emerging countries is volatility. Volatility is the quality of a business/economy environment being risky for trade. In simple terms, it is the rate at which prices change. Although not all emerging countries are alike in every aspect of volatility, it is generally claimed that 'countries with weaker economic fundamentals experienced higher currency volatility and capital flows' [9]. Here the focus would be on ICT developing economic fundamentals and creating opportunities for a more stabilised and robust economy.

As stated earlier, ICT is one of the largest and fastest growing sectors, creating millions of jobs directly and indirectly; this means the emergence of new services, products and even industries. A clear example of this is the growth and development of the telecommunication industry, which provides the infrastructure that is needed to perform business electronically. E-business, e-services, e-commerce, m-commerce (mobile commerce) and Internet marketing are examples of ICT applications that allow people and businesses to exercise online activities.

ICT tools are powerful tools for marketing as they provide businesses with new ways of reaching out to and serving their customers. People now also have access to information and other aspects of the digital era, such as networking and social media, almost in every aspect of their everyday lives.

In addition, ICT has also contributed to the rise of entrepreneurship [10] by facilitating access to various resources for entrepreneurs, namely resources and information on investment, regulatory requirements, marketing, leadership, practices and processes, not to mention social and supportive networks.

ICT also contributes to the growth of Gross Domestic Product (GDP). Here, the importance of broadband for development is worth noting. It is claimed that the impacts of broadband in emerging countries are greater compared to countries with a higher rate of income, with a percentage increase of 1.21 per capita GDP growth, per 10 per cent increase in broadband subscription [11].

Broadband increases efficiency and productivity in the economy, as it provides easier access to information. A high-speed Internet via broadband infrastructure facilitates macroeconomic growth by speeding up the distribution of information and ideas and also promoting competition. Some of the other prospective economic benefits obtained from broadband are: new economic opportunities, employment creation, rising incomes, higher productivity, innovation, lower costs, increased trade and exports, firm efficiency, increasing firm and community competitiveness and growing business links. All of these are examples of the positive impacts of broadband on a country's GDP, gained in several different ways.

\section{ICT and capital markets}

Capital markets play a vital part in the economy of countries. Emerging countries are known to have less mature capital markets. In economics and finance, capital 
market refers to a market system through which buyers and sellers trade in stocks, shares, bonds, commodities, money and currency over a long-term period. What can be inferred from this definition is that a capital market requires strong and persistent communication platforms to link its various components and stakeholders.

ICT infrastructure is crucial to support the capital market and to facilitate its efficient and effective operations [12]. It has undoubtedly smoothed operations in the capital market by improving and accelerating information access, practices and processes in financial markets, trading activities, banking systems, communications, investments etc. It is claimed that 'growth in market capitalisation is affected by the level of interaction between stockbrokers and investors brought about by ICT in the form of Internet access, telephone (mainlines and mobile) as well as access to the websites of stockbrokers' [13].

The use of the Internet, mobile phones, computers, communication networks, hardware and software have facilitated business services. Examples of such facilitations are for large data processing, information transmission, data/information manipulating, better decision-making and strategic management, stakeholder engagement, interaction and collaboration and resourcing.

Technology and communication have also brought about dramatic changes in the realm of business resourcing. Examples of resourcing are offshoring and outsourcing, explained in section 2. Another method of resourcing business is cloud computing. Cloud computing 'delivers infrastructure, platform, and software (application) as services... [and] fosters elasticity and seamless scalability of IT resources that are offered to end users as a service through the Internet' [14, p. 3]. In other words, it allows easy, cost-effective and flexible access to a broad range of resources online and via the Internet. Today, an increasing number of companies and organisations adopt the cloud and benefit from its costeffective pay-per-use pricing basis. As cloud solutions reduce infrastructure, upgrading and maintenance costs [15], they enable a more dynamic and competitive business environment. They can implement and improve low-cost marketing strategies both within a business or industry itself and also in the relationship between businesses and their customers in the capital market.

\section{ICT and return on investment}

According to the definition presented by Oxford Economy [16], capital 'refers to the outcome of any investment, a commitment of current resources with the expectation of future returns' (p. 3). Capital can be in the form of money or assets. The capital investments in ICT include both tangible assets - those that have a physical existence, such as hardware, physical technology, IT infrastructure and communication networks - and intangible assets, which are not physical and are harder to quantify. These include data, knowledge, intellectual property, innovation, etc.

Investment in ICT has delivered a larger return to productivity growth than that of other forms of capital investment. According to Oxford Economy [16], this contribution has been around one-third $-20-25 \%$ - of the overall returns on ICT 
investment, while the returns on other forms of capital investment stand at an average of about $15 \%$.

Research suggests that emerging countries enjoy a higher capacity for providing higher rates of return on investments compared to developed countries. Among various ICT industries, telecommunication, media and digital industries are known to be the most attractive for investment in emerging countries [17]. While emerging countries have generated profits from ICT, they can enhance ICT investment through a number of practices, such as 1) moving to digital processes; 2) free information access and communication; 3) providing incentives based on performance; 4) investing in firm and organisation culture; 5) investing in human resources; 6) employee empowerment and 7) effective recruitment strategies and practices [16].

\section{Discussion and conclusion}

The integration of ICT has positive impacts on various aspects of business and economic life within emerging countries. It supports the sustainability of an emerging economy in multiple ways. Several aspects of ICT's contributions have been enumerated in this research. Findings reveal that the economies of emerging countries can be positively affected by ICT, as it substantially contributes to rapid technological development and economic recovery. These contributions range from people's everyday activities to economic contributions at a national level, including more effective interaction among people and businesses.

In a nutshell, ICT helps in creating jobs, generating income, GDP enhancement, increasing effectiveness and productivity, improving business services and processes, providing accessible information and communication networks, education, innovation and human capital. In addition, ICT helps make more stable economies by promoting economic fundamentals. It also makes economies mature enough to support sustainable capital markets through improving operations via the Internet and broadband.

However, it is argued that adoption of ICT is not entirely free from problems. The benefits of ICT are not seized spontaneously and on their own. Even if technology itself contributes to growth and prosperity, it cannot be claimed that these will be successfully brought about in reality. For example, ICT investment by itself cannot deliver these benefits without being combined with investments in organisational and human capital [16]. Moreover, realising the benefits of ICT integration depends to a large degree on whether and the extent to which emerging countries and their governments appreciate the opportunities, while providing proper policies, regulations and management to ensure that the right supportive conditions are in place [18]. Therefore, government policies play a key part in ICT development, returns on ICT investment and the potential to generate productivity benefits [16].

The deployment of ICT itself also involves burdens and risk in the form of financial limitations and technical complexity. As with any other project, ICT deployments may encounter uncertainty, ambiguity and difficulties in different phases of design, planning, execution, maintenance, etc. Moreover, as ICT is 
associated with high costs in terms of its infrastructure components and technologies, it may end up revealing hidden costs over time, which can lead to failure and further loss.

Considering all the aforementioned, it should be noted that the role of ICT in the economies of countries cannot be ignored. This has been especially so in the case of emerging countries, which need sustainable economies. While the penetration of ICT in the economy of emerging countries continues to increase, there is great demand for proper and sufficient investigation and analysis of existing and prospective opportunities for implementation of any aspects of ICT.

\section{References}

[1] Broner, F. \& Rigobon, R., Why are capital flows so much more volatile in emerging than in developed countries? Proc. of the $8^{\text {th }}$ Annual Conf. of the Central Bank of Chile, "External Financial Vulnerability and Preventive Policies”, Santiago, August 10-11, 2004.

[2] Bilgili, T.V., Kedia, B.L. \& Bilgili, H., Exploring the influence of resource environments on absorptive capacity development: The case of emerging market firms. Journal of World Business, 51(5), pp.700-712, 2016.

[3] Bekaert, G. \& Harvey, C.R., Emerging equity markets in a globalizing world. Netspar Discussion Papers, Tilburg, 2014.

[4] World Bank, ICT for Greater Development Impact, World Bank Group Strategy for Information and Communication Technology, Washington, 2012.

[5] OECD, https://stats.oecd.org/glossary/detail.asp?ID $=6271$

[6] German Federal Ministry for Economic Cooperation and Development, IT Sector Promotion in Developing and Emerging Countries, Deutsche Gesellschaft für Internationale Zusammenarbeit (GIZ), Bonn and Eschborn, 2011.

[7] A.T. Kearney, https://www.atkearney.com/strategic-it/global-serviceslocation-index

[8] OECD, Working Party on the Information Economy, Organisation for Economic Co-operation and Development. Committee for Information, Computer and Communications Policy. Paris, 2007.

[9] Santacreu, A. M., The Economic Fundamentals of Emerging Market Volatility. Economic Synopses, No. 2, pp. 1-2, 2015.

[10] Kotnik, P. \& Stritar, R., ICT as the Facilitator of Entrepreneurial Activity: An Empirical Investigation. Amfiteatru Economic, 17(38), pp. 277-290, 2015.

[11] Qiang, C.Z.W., Rossotto, C.M., \& Kimura, K., Economic Impacts of Broadband (Chapter 3). Extending Reach and Increasing Impact, pp. 3550, 2010.

[12] Central Bank, Importance of Capital Market as an Instrument of Economic Development. CBL Economic Review, No. 109, 2009. 
[13] Ezirim, C. B., Elike, U., \& Muoghalu, M. I., Capital market growth and information technology: Empirical evidence from Nigeria. International Journal of Business and Economics Perspectives, 4(1), pp. 1-17, 2009.

[14] Buyya, R., Introduction to the IEEE Transactions on Cloud Computing. IEEE Transactions on Cloud Computing, 1(1), pp. 3-21, 2013.

[15] Marston, S., Li, Z., Bandyopadhyay, S., Zhang, J. \& Ghalsasi, A., Cloud computing - The business perspective. Decision support systems, 51(1), pp. 176-189, 2011.

[16] Oxford Economics, Capturing the ICT Dividend: Using technology to drive productivity and growth in the EU. Oxford Economics, Oxford, 2012.

[17] Developing Telecoms, http://www.developingtelecoms.com/business/ blogs-opinion/5369-opinion-emerging-markets-present-attractiveinvestment-opportunities.html

[18] World Bank, http://live.worldbank.org/information-communicationstechnology-development 